E-ISSN : 2549-6581

DOI: 10.21776/ub.JOIM.2021.005.02.5

Artikel Hasil Penelitian

Diterima : 10 Mei 2021

Direview : 4 Juni 2021

Dimuat : Agustus - November 2021

\section{OPEN ACCESS}

Journal of Issues in Midwifer

\title{
Literature Review: Intervensi Kebidanan Terkini Peningkatan Sikap Orang Tua dalam Memberikan Pendidikan Seksual Pada Anak untuk Pencegahan Child Sexual Abuse
}

\author{
Hafshah $^{\left.1^{*}\right)}$, Diadjeng Setya Wardani ${ }^{2}$, Kentri Anggarina Gumanti ${ }^{2}$ \\ ${ }^{1 *}$ Program Studi Sarjana Kebidanan, Fakultas Kedokteran, Universitas Brawijaya, Email: \\ hafshah1403@gmail.com , Tlp: +6282113216754 \\ ${ }^{2}$ Program Studi Sarjana Kebidanan, Fakultas Kedokteran, Universitas Brawijaya, Email: \\ diadjeng.wardani@gmail.com ; kentri.ag@gmail.com
}

\begin{abstract}
Child sexual abuse cases reported in Indonesia are still high. Sexual issues are still taboo in society, parents in Indonesia don't care about sexual education for their children. Sexual education is important given to straighten understanding and positive sexual behavior of children. Providing appropriate sexual education can equip children to protect themselves from sexual abuse. Parents need to support and facilities to provide sexual education for their children. This study aimed to critically review literature, articles, and related documents research in measuring the effectiveness of health promotion interventions to improve parents' attitudes in providing sexual education for children as an effort in preventing child sexual abuse. In this study, researchers use the literature review method. Data were obtained from reputable journal articles published in the 2010-2020 period. To analysis the research, researchers use the PICO-T RCAC method (Population, Intervention, Compare / Intervention, Outcome, Time). Ten articles analyzed show that the interventions provided varied greatly in terms of content, methods, media, and duration. Interventions are training, counseling, psychoeducation, and educational drama that can improve parents' knowledge, attitudes, and communication practices in preventing child sexual abuse and increasing parental awareness of the phenomenon of sexual harassment around their children. This study concludes that some health promotion interventions have been effective in improving parents' attitudes to be more positive in providing sexual education to their children.
\end{abstract}

Keywords: Parents' Attitudes, Parents' Perceptions, Sexual Education, Health Promotion, Child Sexual Abuse

\begin{abstract}
ABSTRAK
Kasus pelecehan seksual anak di Indonesia masih tinggi. Masalah-masalah seksual masih dianggap tabu di masyarakat sehingga masih banyak orang tua yang kurang peduli akan pendidikan seksual anak mereka. Pendidikan seksual anak penting diberikan untuk meluruskan persepsi dan perilaku seksual anak menjadi lebih positif. Pemberian pendidikan seksual yang tepat dapat membekali anak dalam melindungi diri sendiri dari kejahatan seksual. Orang tua membutuhkan dukungan dan fasilitas dalam memberikan pendidikan seksual pada anak mereka. Tujuan penelitian ini yaitu menelaah literature,
\end{abstract}


artikel dan dokumen hasil penelitian yang mengidentifikasi efektifitas intervensi kegiatan pendidikan/promosi kesehatan terkini untuk meningkatkan sikap orang tua dalam memberikan pendidikan seksual pada anak sebagai upaya pencegahan pelecehan seksual. Metode penelitian yang digunakan adalah Literature Review. Data yang digunakan berasal dari artikel jurnal bereputasi yang dipublikasikan pada rentang periode 2010-2020. Analisis hasil penelitian menggunakan RCAC metode PICO-T (Population, Intervention, Compare/intervention, Outcome, Time). Hasil dari 10 jurnal penelitian yang dianalisis, menunjukan bahwa intervensi yang diberikan sangat bervariasi dari segi konten, metode, media maupun durasinya. Intervensi dalam bentuk pelatihan, konseling, psikoedukasi dan permainan drama mampu meningkatkan pemahaman, sikap, dan praktik orang tua dalam mencegah terjadinya kekerasan seksual pada anak, serta meningkatkan kesadaran akan fenomena pelecehan seksual disekelilling anak-anak mereka. Kesimpulan dari penelitian ini yaitu intervensi dalam bentuk pendidikan/promosi kesehatan terkini dapat meningkatkan nilai sikap orang tua menjadi lebih positif dalam memberikan pendidikan seksual pada anak mereka secara signifikan.

Kata kunci: Sikap Orang Tua, Persepsi Orang Tua, Pendidikan Seksual, Promosi Kesehatan, Pelecehan Seksual

*Korespondensi: Hafshah. Surel: hafshah1403@gmail.com

\section{PENDAHULUAN}

Kasus child sexual abuse (CSA) atau pelecehan seksual anak di Indonesia masih cukup tinggi. Komisi Perlindungan Anak Indonesia (KPAl) mencatat ada 458 aduan kasus CSA di tahun 2018. Pada Januari 2019 hingga Mei 2019 tercatat 236 kasus CSA yang dilaporkan. Angka tersebut hanya berdasarkan pengaduan, belum menggambarkan kasus CSA yang terjadi sebenarnya ${ }^{(1)}$.

\section{Berdasarkan Data Sistem} Informasi Online Perlindungan Perempuan dan Anak (SIMFONI PPA), pada periode 1 Januari - 31 Juli 2020 jumlah anak korban kekerasan seksual mencapai 2.556 anak dari total 4.116 kasus. Jumlah kasus terus mengalami penambahan pada bulan Agustus mencapai 4.833 kasus. Menurut Kementerian Perlindungan Perempuan dan Anak (Kemen PPA), dua dari tiga anak di Indonesia pernah mengalami tindak kekerasan baik secara verbal maupun nonverbal.
Selain berdampak pada masalah kesehatan di kemudian hari, CSA berkaitan dengan trauma yang berkepanjangan. Secara fisik memang mungkin tidak ada hal yang harus dipermasalahkan pada anak yang menjadi korban CSA, namun, secara psikis bisa menimbulkan ketagihan, trauma, bahkan pelampiasan dendam. Bila tidak ditangani serius, CSA dapat menimbulkan dampak sosial yang luas di masyarakat ${ }^{(2)}$.

Pengalaman seksual yang kurang tepat juga dapat membuat anak memiliki persepsi yang salah terkait alat dan proses reproduksi, serta seksualitasnya. Jika dibiarkan, hal tersebut dapat menyebabkan anak mengalami kekeliruan perilaku seks dikemudian hari ${ }^{(3)}$. Disamping itu, anak juga memiliki rasa keingintahuan yang tinggi. Apabila anak tidak menemukan jawaban atas rasa ingin tahunya, mereka cenderung akan mencari informasi melalui teman sebaya maupun sumber lain. Informasi tersebut belum tentu benar dan bisa saja menyesatkan ${ }^{(4)}$. 
Sebagai guru pertama bagi anak, orang tua bertanggung jawab dalam hal tersebut. Orang tua berkontribusi dalam mendidik, mengasuh dan membentuk watak seorang anak ${ }^{(5)}$.

Hingga saat ini masalah seksual di Indonesia masih dianggap tabu. Masih banyak orang tua yang kurang peduli dan merasa risih membicarakan masalah seksual dengan anak mereka ${ }^{(6)}$. Oleh karena itu, orang tua membutuhkan dukungan dan fasilitas dalam hal tersebut. Bidan sebagai edukator dan promotor berperan penting dalam membimbing, mendukung dan meningkatkan kesadaran orang tua akan pentingnya pendidikan seksual bagi anak.

Penelitian ini bertujuan menelaah artikel hasil penelitian terkait efektifitas intervensi kegiatan promosi kesehatan terkini untuk meningkatkan sikap orang tua dalam memberikan pendidikan seksual terhadap anak mereka sebagai upaya pencegahan CSA.

\section{METODE PENELITIAN}

Metode yang digunakan dalam penelitian ini adalah metode literature review dimana peneliti mengkaji secara kritis gagasan yang terdapat didalam literatur untuk topik tertentu. Dalam penelitian ini, peneliti menelaah intervensi berbentuk kegiatan promosi kesehatan untuk meningkatkan sikap orang tua dalam memberikan pendidikan seksual terhadap anak mereka sebagai upaya pencegahan child sexual abuse.

Data yang digunakan dalam penelitian ini berasal dari artikel jurnal online bereputasi yang dipublikasikan di internet. Pencarian jurnal menggunakan database dengan kriteria kualitas sedang dan tinggi dengan memasukan kata kunci "attitudes", "perceptions", "opinions", "sex education", "revention program", "revention strategies", "child sexual abuse", "child sexual assault". Artikel yang digunakan adalah 10 artikel yang diterbitkan dalam sepuluh tahun terakhir (2010-2020). Hasil seleksi artikel studi digambarkan dalam Diagram Flow pada Gambar 1. 


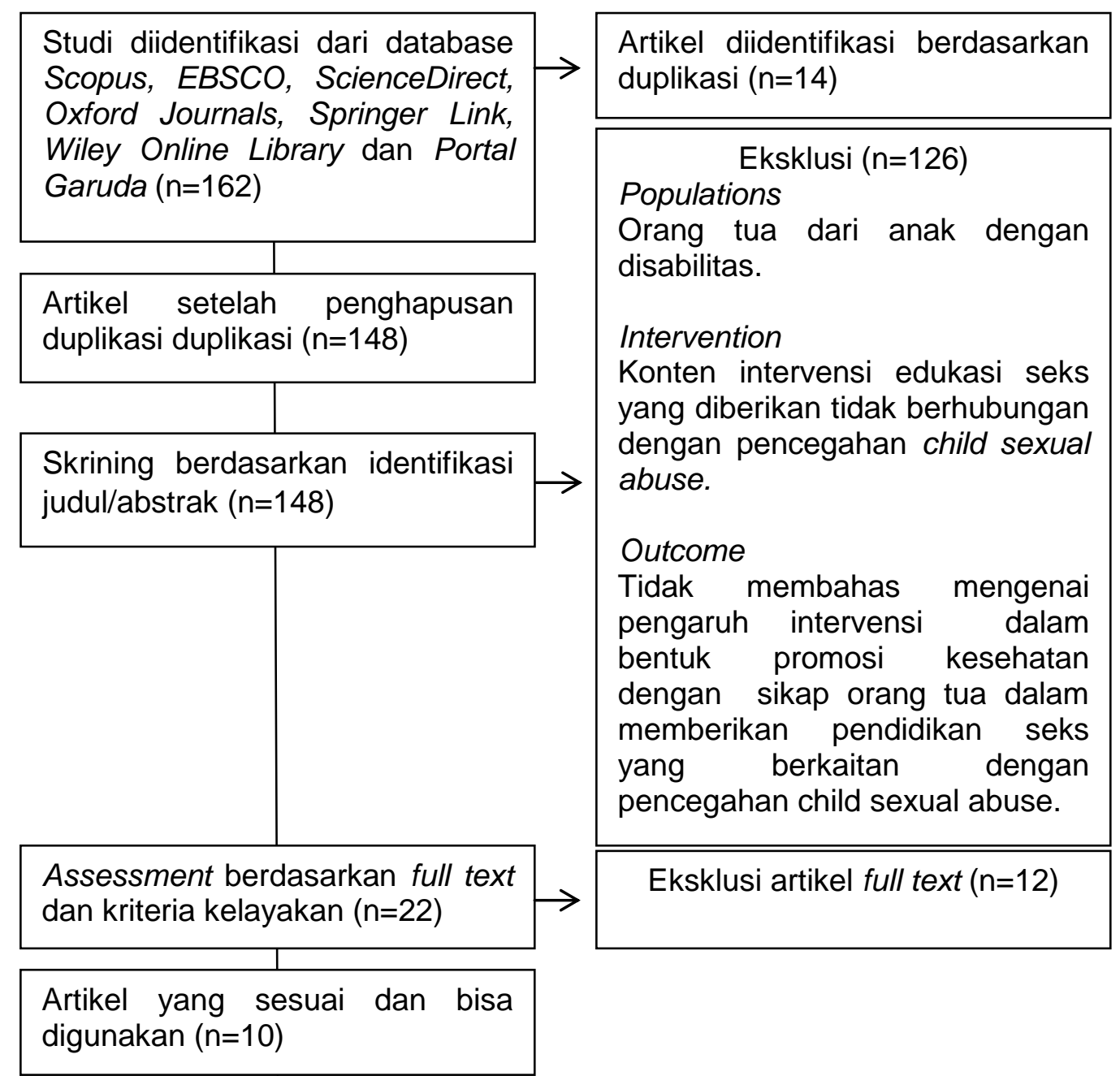

\section{Gambar 1. Diagram Flow Literature Review berdasarkan PRISMA 2009 (Maher, et al., 2009)}

Data yang ditemukan akan dievaluasi berdasarkan pertanyaan kriteria penilaian kualitas (Quality Assesment) dan analisis jurnal hasil penelitian menggunakan RCAC metode PICO-T (Population, Intervention, Compare / intervention, Outcome, Time) dengan ketentuan $\mathrm{P}$ adalah orang tua yaitu ayah dan ibu dari seorang anak, I adalah intervensi dengan konten edukasi seksual, C adalah intervensi pembanding, $O$ adalah sikap orang tua dalam memberikan pendidikan seksual pada anak dan $\mathrm{T}$ adalah tahun pelaksanaan penelitian.

\section{HASIL PENELITIAN}

Sepuluh studi yang dianalisis dalam literature review ini memenuhi kriteria inklusi sesuai dengan topik yang ditentukan yaitu intervensi dalam bentuk kegiatan pendidikan atau promosi kesehatan terhadap perubahan sikap orang tua dalam memberikan pendidikan seksual terhadap anak mereka. Desain penelitian studi yang digunakan sebagian besar berbentuk Quasi-Eksperimental dan Randomised Controlled Trial (RCT). Hasil analisis penelitian dituangkan dalam Tabel 1. 
Tabel 1. Hasil Sintesis Data

\begin{tabular}{|c|c|c|c|c|c|}
\hline No. & Judul & Population & Intervention & $\begin{array}{l}\text { Comparison } \\
\text { Intervention }\end{array}$ & Outcome \\
\hline 1. & $\begin{array}{l}\text { Audiovisual } \\
\text { Health } \\
\text { Promotion } \\
\text { (Septiani et } \\
\text { al., 2016) }\end{array}$ & $\begin{array}{l}64 \text { Ibu dari } \\
\text { anak usia } \\
\text { pra-sekolah } \\
\text { (3-6 tahun), }\end{array}$ & $\begin{array}{l}\text { Ceramah } \\
\text { audiovisual }\end{array}$ & $\begin{array}{l}\text { Leaflet tanpa } \\
\text { fasilitator }\end{array}$ & \begin{tabular}{lrr}
\multicolumn{2}{l}{ Peningkatan persepsi } & ibu \\
terkait pentingnya & sex \\
education bagi anak pra- \\
sekolah lebih tinggi & $(58,5)$ \\
dengan selisih & 5,3 \\
dibandingkan pada kelompok \\
kontrol $(56,5)$ dengan selisih \\
0,4 .
\end{tabular} \\
\hline 2. & $\begin{array}{l}\text { Children's } \\
\text { Play "Yaael } \\
\text { Learns to } \\
\text { Take Care } \\
\text { of Her } \\
\text { Body" } \\
\text { (Gesser- } \\
\text { Edelsburg } \\
\text { et al., 2017) }\end{array}$ & $\begin{array}{l}20 \text { orang tua } \\
\text { (4 laki-laki } \\
\text { dan } 16 \\
\text { perempuan) } \\
\text { dari anak- } \\
\text { anak berusia } \\
5-8 \text { tahun }\end{array}$ & Drama & $\begin{array}{l}\text { Tidak ada } \\
\text { kelompok } \\
\text { kontrol }\end{array}$ & $\begin{array}{l}\text { Aspek afektif (perasaan +) } \\
\text { orang tua terkait kasus CSA } \\
\text { meningat dan ketakutan orang } \\
\text { tua untuk berdiskusi masalah } \\
\text { seks dengan anak mereka } \\
\text { menurun. }\end{array}$ \\
\hline 3. & $\begin{array}{l}\text { Sex } \\
\text { Education } \\
\text { Programme } \\
\text { (Martin et } \\
\text { al., 2018) }\end{array}$ & $\begin{array}{l}80 \text { Ibu dari } \\
\text { anak-anak } \\
\text { pra-sekolah } \\
\text { (usia 3-6 } \\
\text { tahun) }\end{array}$ & $\begin{array}{l}2 x \text { sesi } \\
\text { ceramah dan } \\
\text { diskusi } \\
\text { kelompok }\end{array}$ & $\begin{array}{l}\text { Tidak diberikan } \\
\text { perlakuan }\end{array}$ & $\begin{array}{l}\text { Peningkatan } \\
\text { pengetahuan ibu dkor } \\
\text { memberikan sex education } \\
\text { pada anak mereka sebelum } \\
(19,6) \text { dan sesudah }(28,72) \\
\text { intervensi }(p<0,001) \text {. Rerata } \\
\text { skor sikap ibu sebelum } \\
\text { intervensi }(96,27) \text { dan sesudah } \\
(110,25) \text { intervensi juga } \\
\text { mengalami peningkatan yang } \\
\text { signifikan }(p<0,001) \text {. }\end{array}$ \\
\hline 4. & $\begin{array}{l}\text { Group } \\
\text { Education } \\
\text { and } \\
\text { Education } \\
\text { by } \\
\text { Multimedia } \\
\text { Compact } \\
\text { Disk (Lak et } \\
\text { al., 2018) }\end{array}$ & $\begin{array}{l}100 \text { orang } \\
\text { ibu dari anak } \\
\text { usia di } \\
\text { bawah } 18 \\
\text { tahun }\end{array}$ & $\begin{array}{l}2 x \text { sesi } \\
\text { ceramah, } \\
\text { film, berbagi } \\
\text { pengalaman } \\
\text { ibu XCD } \\
\text { dengan } \\
\text { konten yang } \\
\text { sama }\end{array}$ & $\begin{array}{l}\text { CD tanpa sesi } \\
\text { ceramah }\end{array}$ & $\begin{array}{l}\text { Peningkatan pengetahuan dan } \\
\text { sikap orang tua tentang CSA } \\
\text { setelah intervensi dalam group } \\
\text { education }(92,6 \text { dan } 84,1) \\
\text { dibandingkan sebelum } \\
\text { intervensi }(69,7 \text { dan } 58,4) \text { dan } \\
\text { juga peningkatan dalam } \\
\text { kelompok CD multimedia } \\
\text { setelah intervensi ( } 92,3 \text { dan } \\
81,4) \text { dibandingkan dengan } \\
\text { sebelum intervensi }(67,5 \text { dan } \\
56) \text {. }\end{array}$ \\
\hline 5. & $\begin{array}{l}\text { Group } \\
\text { Counseling } \\
\text { (Navaei et } \\
\text { al., 2018) }\end{array}$ & 62 orang tua & $\begin{array}{l}3 x \text { sesi } \\
\text { konseling } \\
\text { kelompok (1 } \\
\text { bulan) }\end{array}$ & $\begin{array}{l}\text { Tidak ada } \\
\text { kelompok } \\
\text { kontrol }\end{array}$ & $\begin{array}{l}\text { Peningkatan pengetahuan, } \\
\text { sikap dan self-efficacy orang } \\
\text { tua pada kasus CSA. }\end{array}$ \\
\hline
\end{tabular}


Tabel 1. Hasil Sintesis Data

\begin{tabular}{|c|c|c|c|c|c|}
\hline No. & Judul & Population & Intervention & $\begin{array}{l}\text { Comparison } \\
\text { Intervention }\end{array}$ & Outcome \\
\hline 6. & $\begin{array}{l}\text { Sexual } \\
\text { Education } \\
\text { Program } \\
\text { (Mobredi et } \\
\text { al., 2018) }\end{array}$ & $\begin{array}{l}78 \text { ibu dari } \\
\text { anak-anak } \\
\text { prasekolah (3- } \\
6 \text { tahun) }\end{array}$ & $\begin{array}{l}4 x \text { sesi } \\
\text { ceramah } \\
\text { dan diskusi }\end{array}$ & $\begin{array}{l}\text { Tidak diberikan } \\
\text { perlakuan }\end{array}$ & $\begin{array}{l}\text { Skor rata-rata pengetahuan } \\
\text { ibu dalam memberikan sex } \\
\text { education ke anak mereka } \\
\text { meningkat dari } 27,23 \\
\text { menjadi } 34,2 \text { segera dan } \\
\text { menjadi } 37,44 \text { delapan } \\
\text { minggu setelah pemberian } \\
\text { program sex education. Skor } \\
\text { rata-rata sikap secara } \\
\text { signifikan meningkat dari } \\
48,54 \text { menjadi } 59,15 \text { segera } \\
\text { dan } 64,49 \text { delapan minggu } \\
\text { setelah intervensi. Dan tidak } \\
\text { ada perbedaan yang } \\
\text { signifikan pada kelompok } \\
\text { kontrol. }\end{array}$ \\
\hline 7. & $\begin{array}{l}\text { Group } \\
\text { Training } \\
\text { (Rousta et al., } \\
\text { 2019) }\end{array}$ & $\begin{array}{l}90 \text { ibu dari } \\
\text { anak laki-laki } \\
\text { usia 12-14 } \\
\text { tahun }\end{array}$ & $4 x$ ceramah & $\begin{array}{l}\text { Tidak diberikan } \\
\text { perlakuan }\end{array}$ & \begin{tabular}{lr} 
Peningkatan & \multicolumn{2}{r}{ skor } \\
pengetahuan & \multicolumn{2}{c}{ ibu } \\
sehubungan & \multicolumn{2}{c}{ dengan } \\
pendidikan & kesehatan \\
seksual remaja muda $(P$ \\
$<0,001)$ dan sikap (P \\
$<0,001)$.
\end{tabular} \\
\hline 8. & $\begin{array}{l}\text { CSA Training } \\
\text { Program } \\
\text { (Apaydın } \\
\text { Cirık et al., } \\
\text { 2020) }\end{array}$ & $\begin{array}{l}58 \text { anak (usia } \\
3 \text { tahun) - } 6 \\
\text { tahun) dan } 64 \\
\text { orang tua }\end{array}$ & $\begin{array}{l}\text { Kursus } \\
\text { harian -> } \\
\text { estafet } \\
\text { keanak } \\
\text { selama } 1 \\
\text { bulan }\end{array}$ & $\begin{array}{l}\text { Tidak ada } \\
\text { kelompok } \\
\text { kontrol }\end{array}$ & $\begin{array}{l}\text { Peningkatan pengetahuan } \\
\text { orang tua serta komunikasi } \\
\text { orang tua-anak tentang } \\
\text { pencegahan } \\
\text { Pengetahuan anak tentang } \\
\text { CSA juga meningkat melalui } \\
\text { pendidikan yang diberikan } \\
\text { orang tuanya. }\end{array}$ \\
\hline 9. & $\begin{array}{l}\text { Parenting } \\
\text { Sexual } \\
\text { Education } \\
\text { Program } \\
\text { (Practical } \\
\text { Booklet \& } \\
\text { Booster } \\
\text { Session) } \\
\text { (Lee et al., } \\
2020\end{array}$ & $\begin{array}{l}132 \text { Orang tua } \\
\text { imigran darii } \\
\text { anak usia 6-18 } \\
\text { tahun }\end{array}$ & $\begin{array}{l}\text { Buklet, sesi } \\
\text { booster } \\
\text { (ceramah, } \\
\text { video dan } \\
\text { bermain } \\
\text { peran) }\end{array}$ & $\begin{array}{l}\text { Kelompok } \\
\text { kontrol tidak } \\
\text { diberikan } \\
\text { intervensi }\end{array}$ & $\begin{array}{l}\text { Peningkatan pengetahuan ( } p \\
<0.001) \text {, sikap }(p<0.001) \text {, } \\
\text { self-efficacy }(p<0.001) \text { dan } \\
\text { praktik }(p<0.001) \text { orang tua } \\
\text { terhadap sex education pada } \\
\text { anak. }\end{array}$ \\
\hline 10. & $\begin{array}{l}\text { Psikoedukasi } \\
\text { Pendidikan } \\
\text { (Joni \& } \\
\text { Surjaningrum, } \\
\text { 2020) }\end{array}$ & $\begin{array}{l}10 \text { orang guru } \\
\text { dan } 15 \text { orang } \\
\text { tua murid dari } \\
3 \text { taman } \\
\text { kanak-kanak } \\
\text { (TK) yang } \\
\text { berbeda }\end{array}$ & $\begin{array}{l}\text { Ceramah, } \\
\text { diskusi dan } \\
\text { isi lembar } \\
\text { worksheet }\end{array}$ & $\begin{array}{l}\text { Tidak ada } \\
\text { kelompok } \\
\text { kontrol }\end{array}$ & $\begin{array}{l}\text { Peningkatan pemahaman } \\
\text { guru dan orang tua terkait } \\
\text { kekerasan seksual. Nilai } \\
\text { signifikansi pada gain score } \\
\text { kekerasan seksual sebesar } \\
0.000 \text { (sig. < } 0.05 \text { ). }\end{array}$ \\
\hline
\end{tabular}

Audiovisual Health Promotion ${ }^{(7)}$

Dalam penelitian ini, intervensi yang diberikan berbentuk promosi kesehatan melalui metode ceramah dengan membandingkan penggunaan media audiovisual dan leaflet. Topik yang diangkat yaitu urgensi sex education bagi anak usia pra-sekolah. Penyampaian materi difasilitasi oleh fasilitator. Kombinasi metode ceramah dan penggunaan media audiovisual efektif dalam merubah persepsi ibu dalam memberikan pendidikan 
seksual pada anak. Namun, penggunaan leaflet tanpa fasil kurang efektif dalam merubah persepsi ibu.

\section{Children's Play "Yael Learns to Take Care of Her Body",(8)}

Orang tua menonton pertunjukan drama "Yael Learns to Take Care of Her Body" bersama anak-anak mereka. Drama ini dimainkan oleh seorang aktris cilik yang berperan sebagai Yael, gadis berusia 5-7 tahun. Yael memerankan sejumlah situasi dari kehidupan pribadinya di mana ia menghadapi konflik mengenai bagaimana melindungi tubuhnya dan mencegah dari pelecehan seksual. Drama ini berisi lagu dan diskusi antara aktris bersama anakanak. Karakter Yael dirancang sedemikian rupa sehingga ia memenuhi kondisi untuk dijadikan panutan. Setelah menonton drama beberapa orang tua setuju terkait pemberian pendidikan seksual pada anak dan menjadikan drama tersebut sebagai alat berdiskusi tentang pelecehan seksual dengan anak-anak mereka.

\section{Sex Education Programme ${ }^{(9)}$}

Program ini merupakan program pelatihan sex education bagi orang tua anak pra-sekolah yang diberikan melalui metode ceramah, tanya jawab dan diskusi kelompok. Program diberikan dua kali sesi pertemuan dimana satu sesi berdurasi 2 jam. Isi pelatihan pada sesi pertama memperkenalkan tujuan dan pentingnya pendidikan seks, tahapan perkembangan seksual anak usia 3-6 tahun, identitas seksual dan peran orang tua dalam pembentukan identitas seksual berdasarkan jenis kelamin anak. Tema pendidikan seksual yang tepat untuk anak-anak usia 3-6 tahun yaitu seperti tempat tidur, mandi, menyentuh, membelai, dan cara membiasakan anak dengan organ genitalnya. Pelatihan sesi kedua terdiri dari pembahasan mengenai bagaimana memberikan tanggapan yang sesuai saat anak bertanya mengenai masalah seksual, mengidentifikasi hal-hal yang layak dan tidak pantas dilakukan, dan cara melindungi anak dari pelecehan seksual. Program ini efektif meningkatkan pengetahuan sekaligus sikap ibu dari anak-anak pra-sekolah dalam memberikan pendidikan seksual terhadap anak mereka.

\section{Group Education and Education by Multimedia Compact Disk ${ }^{(10)}$}

Peneliti membagi subjek menjadi dua kelompok yaitu Group Education dan kelompok Compact Disk. Peneliti memberikan pelatihan dengan dua sesi pendidikan 2 jam selama 2 minggu berturut-turut. Metode yang digunakan dalam Group Education meliputi ceramah, menonton film animasi, berbagi pengalaman ibu, dan tanya jawab. Konten pendidikan yang diberikan seputar pelecehan seksual pada anak. Sedangkan pada kelompok Compact Disk (CD) peneliti membagikan CD edukasi (dengan konten pendidikan yang sama dengan yang ada di sesi Group Education). CD yang dibagikan berisi teks, audio, gambar, film, dan animasi pendidikan. Metode Group Education dan Compact Disk sama efektifnya dalam meningkatkan pengetahuan sekaligus sikap ibu tentang pelecehan seksual anak. 


\section{Group Counseling ${ }^{(11)}$}

Dalam penelitian ini, orang tua di bagi menjadi lima subkelompok (dengan anggota tiap kelompok 6-7 orang). Setiap kelompok diberikan sesi konsultasi dengan jadwal yang berbeda. Sesi konsultasi terdiri dari 90 menit tiap sesi per minggunya, selama 3 minggu berturut-turut. Sesi ini diawasi oleh ahli yang berspesialisasi dalam kebidanan dan psikiatri dengan pengalaman konseling 10-12 tahun. Konsultasi berbasis komunikasi direncanakan dan dilakukan sesuai dengan langkah konsultasi GATHER (Greet, Ask, Tell, Help, Explain, and Return). Konseling efektif dalam meningkatkan self-efficacy orang tua pada pelecehan seksual anak.

\section{Sexual Education Program ${ }^{(12)}$}

Dalam penelitian ini, ibu sebagai responden dibagi menjadi beberapa kelompok dengan jumlah peserta tiap kelompok 6-10 orang. Tiap kelompok mengikuti empat sesi program pendidikan seksual, yang dilaksanakan satu sesi perminggu. Tiap kelompok dilatih pada waktu yang berbeda. Setiap sesi terdiri dari kuliah/ceramah, tanya jawab dan diskusi kelompok. Selain itu, para ibu menonton dua film pendek, tentang berbagai jenis sentuhan, bagian pribadi tubuh dan pelecehan terkait dengan berbagai sentuhan. Setiap sesi berlangsung sekitar satu setengah jam. Konten yang diberikan meliputi pentingnya pendidikan seksual anak, peran orang tua dalam pendidikan seksual anak, usia yang sesuai untuk pendidikan seksual anak, pertanyaan seksual anak dan kekhawatiran orang tua tentang pertanyaan-pertanyaan tersebut. selain itu, ibu juga diajarkan berbagai metode pemberian pendidikan seksual anak dan cara mencegah pelecehan seksual pada anak. Topik-topik tersebut disesuaikan dengan latar belakang budaya masyarakat. Setelah delapan minggu pasca program pendidikan terdapat peningkatan pengetahuan dan sikap ibu dalam memberikan pendidikan seksual ke anak-anak mereka.

\section{Group Training ${ }^{(13)}$}

Pada studi ini, para ibu dibentuk menjadi beberapa kelompok dengan individu tiap kelompok beranggotakan 10-11 orang. Ibu sebagai responden diberikan intervensi berupa Group Training. Group Training diberikan sebanyak empat sesi pertemuan dengan interval antar pertemuan satu minggu. Durasi tiap sesi adalah 60 menit dengan rincian kuliah (45 menit) dan tanya jawab (15 menit). Penyampaian materi menggunakan media power point. Konten yang diberikan tiap sesinya berbeda. Group Training, terbukti dapat meningkatkan pengetahuan dan sikap ibu sehubungan dengan pendidikan seksual pada anak remaja pria.

\section{CSA Training Program ${ }^{(14)}$}

Dalam penelitian ini, orang tua dari anak usia 0-6 tahun sebagai responden diberikan intervensi berupa program pelatihan pencegahan CSA. Program ini berupa kursus harian yang berlangsung selama 120 menit dan dibagi menjadi empat tahap. Orang tua yang menyelesaikan pelatihan kemudian diminta untuk meneruskan pelatihan untuk anakanak mereka. Para orang tua 
diberikan salinan poster, ilustrasi, dan buku yang digunakan selama pelatihan sehingga mereka dapat memanfaatkan sumber daya ini dalam mendidik anak-anak mereka sendiri. Para orang tua menyampaikan apa yang telah mereka pelajari kepada anak-anak mereka dalam 1 bulan setelah menyelesaikan pelatihan. Peneliti mengumpulkan masalah yang dihadapi orang tua selama mengajarkan pendidikan seksual kepada anak mereka. Setelah mengevaluasi efektivitas pendidikan yang diberikan orangtua kepada anak, peneliti melakukan pelatihan CSA tambahan untuk anak-anak. Program pelatihan pencegahan CSA efektif untuk meningkatkan pengetahuan orang tua serta komunikasi orang tua dan anak.

\section{Parenting Sexual Education Program Practical Booklet \& Booster Session ${ }^{(15)}$}

Dalam penelitian ini, orangtua imigran diberikan intervensi berupa Parenting Sex Education dalam bentuk buklet dan sesi booster. Buklet, The Magic Book of Love: A Parenting Sexual Education Program Handbook for Immigrant Parents dirancang oleh tim peneliti dan empat spesialis dalam bidang pendidikan seks. Sesi booster dilaksanakan selama 150 menit dimulai dengan pengenalan topik, diikuti dengan pelatihan yang tercantum dalam buklet. Strategi pengajaran yang digunakan berupa ceramah, diskusi, menonton video, dan latihan bermain peran. Program pendidikan seksual menggunakan buklet dan sesi booster efektif dalam meningkatkan pengetahuan, sikap, self-efficacy dan praktik pendidikan seksual orang tua di antara sekelompok orang tua imigran.

\section{Psikoedukasi Pendidikan ${ }^{(16)}$}

Dalam penelitian ini, responden diberikan empat sesi pelaksanaan intervensi dengan topik seputar kekerasan seksual pada anak. Intervensi diberikan dengan metode ceramah, tanya jawab dan pengisian lembar worksheet. Lembar worksheet digunakan orang tua untuk merancang metode kegiatan pendidikan seksual pada anak-anak mereka. Pengerjaan lembar worksheet bertujuan untuk menggali penguasaan materi sekaligus brain storming peserta setelah pemberian intervensi. Psikoedukasi pendidikan seksual terbukti meningkatkan wawasan orang tua terkait pencegahan kekerasan seksual pada anak.

\section{PEMBAHASAN}

Pelecehan seksual anak atau child sexual abuse merupakan masalah kesehatan penting yang harus dicegah karena dapat menyebabkan komplikasi serius pada kehidupan anak. Program pencegahan CSA menjadi tanggung jawab seluruh tatanan masyarakat. Informasi terkait pencegahan CSA sebaiknya diberikan kepada seluruh profesi yang berhubungan dengan anak, orang tua, masyarakat dan lembaga publik terkait.

Fokus utama pencegahan primer melalui program pendidikan seksual bertujuan untuk mengenali, mengatasi dan melaporkan kejadian CSA. Bidan memiliki tanggung jawab utama dalam pencegahan CSA yaitu dengan memberikan pendidikan, perlidungan dan pengembangan kesehatan seksual karena bidan merupakan profesional 
kesehatan yang berhubungan langsung baik dengan anak maupun dengan orang tua.

\section{Intervensi Promosi Kesehatan dalam Pendekatan Pendidikan Seks}

Dalam 10 studi yang dianalisis, intervensi promosi kesehatan yang diberikan dalam penelitian berupa program pendidikan seksual dengan bentuk metode yang bervariasi diantaranya yaitu: 3 penelitian menggunakan metode ceramah ${ }^{(7,10,13)}, 4$ penelitian menggabungkan metode ceramah dengan diskusi kelompok ${ }^{(9,12,15,16)}, 1$ penelitian menggunakan metode drama dan interview (wawancara) ${ }^{(8)}$, 1 penelitian menggunakan metode konseling $^{(11)}$, dan 1 penelitian lainnya menggunaakan metode pelatihan kursus harian ${ }^{(14)}$. Pemberian program pendidikan didukung dengan penggunaan media seperti leaflet, PPT, lembar worksheet, video/film edukasi, poster edukasi, animasi, gambar/foto, lagu, modul, dan buklet. Dari keseluruhan artikel penelitian yang ditelaah menunjukan bahwa sebagian besar kelompok intervensi mengalami peningkatan hasil yang lebih baik dibandingkan dengan kelompok kontrol.

Teori Kerucut Pengalaman Dale menunjukkan bahwa metode/alat bantu peraga yang berbeda akan menghasilkan perubahan pemahaman yang berbeda pula ${ }^{(17)}$. Jika menelaah dari 10 jurnal yang di review, metode kursus harian dalam penelitian Apaydin et al., (2020) menduduki urutan teratas pertama dan metode drama dalam penelitian Gesser-Edelsburg et al., (2017) menduduki urutan teratas ketiga pada teori kerucut pengalaman ini. Pemberian kursus harian dan drama melibatkan pengalaman bersama anak secara langsung. Pengalaman langsung akan melibatkan seluruh pengindraan manusia termasuk perasaan $^{(17)}$. Melalui drama, partisipan (anak) berperan aktif secara langsung, dan observan (orang tua) menonton dan mengamati, sehingga keduanya semakin merasakan langsung dan semakin mengerti materi yang dipelajarkan. Kedua metode tersebut dinilai lebih efektif dalam meningkatkan sikap maupun perilaku orang tua dalam memberikan pendidikan seksual kepada anak mereka.

Beberapa penelitian memilih membagi kelompok menjadi beberapa kelompok kecil. Diskusi kelompok dengan partisipan yang lebih kecil akan membuat diskusi menjadi lebih aktif. Pada diskusi kelompok, seseorang cenderung akan berpikir lebih kritis dalam memecahkan suatu masalah dan mendalami topik tertentu, sehingga retensi penyimpanan informasi menjadi lebih kuat $^{(18)}$. Pada penelitian Navaei et al., (2018), konseling kelompok terbukti dapat meningkatkan pengetahuan, sikap dan self-efficacy orang tua tentang pendidikan seksual dalam topik pelecehan seksual anak.

Intervensi promosi kesehatan dalam pendekatan pendidikan memiliki metode yang sangat beragam. Pemilihan intervensi metode yang tepat dapat disesuaikan dengan karakteristik target sasaran dan kebutuhan masyarakat. Penggunaan metode yang tepat memudahkan responden dalam menerima dan menyimpan informasi yang didapatkan. 


\section{Sikap Orangtua}

Dari 10 jurnal penelitian yang dikritisi, 7 jurnal mengamati nilai variabel sikap orang tua (dalam memberikan pendidikan seksual pada anak mereka) secara langsung dan 3 jurnal lainnya mengamati pengetahuan $^{(16)}$ dan persepsi orang tua ${ }^{(7,8)}$ yang dikaitkan dengan sikap serta keterampilan orang tua dalam memberikan pendidikan seksual pada anak. Keseluruhan jurnal penelitian menunjukkan bahwa intervensi yang diberikan berhasil meningkatkan nilai variabel sikap secara signifikan. Namun, hasil penelitian Gesser-Edelsburg et al (2017), menunjukkan beberapa variasi yang berbeda. Edelsburg menemukan bahwa sebagian besar orang tua cukup siap dalam memberikan edukasi seksual pada anak-anak mereka namun beberapa lainnya menunjukkan sikap negatif. Menurut Transtheoretical Model (TTM) yang dikenalkan oleh James Prochaska, John Norcross dan Arlo DiClemente, perubahan perilaku seseorang berfokus pada kemampuan individu dalam mengambil keputusan. Berdasarkan teori TTM seorang individu menjalani perubahan perilaku melalui lima proses tahapan yaitu: Pre-contemplation, Contemplation, Preparation, Action, dan Maintanance. Dalam tahap precontemplation individu cenderung belum sadar akan adanya suatu masalah $^{(19)}$. Ada kemungkinan, orang tua yang menunjukkan sikap negatif dalam memberikan pendidikan seksual pada anak berada dalam tahap precontemplation ini. Oleh karena itu, komunikasi atau pemberian informasi disini sangat berperan penting dalam menumbuhkan kesadaran.

Terkait dengan hubungan pengetahuan, persepsi dan sikap dapat dijelaskan sebagai berikut. Teori Reasoned Action (TRA) yang dicetuskan oleh Fishbein \& Ajzein, menerangkan bahwa seseorang memiliki kecenderungan menerima maupun menolak suatu informasi yang didapatkan berdasarkan keyakinan dan pengalaman pribadinya ${ }^{(20)}$. Informasi yang tidak dikehendaki akan dibuang karena menimbulkan kecemasan dan informasi yang terpilih akan dikumpulkan menjadi sebuah pengetahuan. Peningkatan pengetahuan akan mempengaruhi perubahan persepsi. Pada proses ini akan timbul respon tergantung latar belakang atau pengalaman yang memengaruhi nilai dan sikap seseorang. Melalui sikap akan terbentuk suatu niatan dan niatan tersebut akan direalisasikan menjadi sebuah tindakan/ perilaku.

\section{Pencegahan Child Sexual Abuse}

Dari 10 jurnal penelitian yang dianalisis, hanya 5 jurnal yang membahas pemberian pendidikan seksual kepada anak terfokus pada pencegahan child sexual abuse ${ }^{(8,10,11,14,16)}$ sedangkan 5 studi lainnya membahas terkait pemberian pendidikan seksual pada anak secara umum, disisipi sedikit pengenalan child sexual abuse. Intervensi dalam bentuk promosi kesehatan mampu meningkatkan pemahaman, sikap, dan praktik orang tua dalam memberikan pendidikan seksual terhadap anak serta meningkatkan kesadaran orang tua akan fenomena pelecehan seksual di sekelilling anak-anak mereka. Secara garis 
besar, orang tua memiliki kesadaran akan perannya dalam melindungi anak-anak mereka dari kekerasan/ pelecehan seksual.

Tujuan utama dari pemberian pendidikan seksual pada anak adalah sebagai upaya pencegahan dan pengurangan kasus kekerasan seksual anak. Melalui pemberian pendidikan seksual, anak menjadi tahu bagaimana harus bersikap dalam mengidentifikasi keadaankeadaan yang membahayakan dirinya dalam konteks seksual. Mengajarkan pengenalan organorgan pribadi, bentuk sentuhan tidak wajar, menghindari interaksi dengan orang yang mencurigakan serta mengajarkan cara mencari pertolongan saat berada dalam kondisi membahayakan, dapat menjadi bekal anak untuk melindungi dirinya sendiri.

\section{SIMPULAN}

Hasil review 10 jurnal sample penelitian yang digunakan menunjukkan bahwa intervensi dalam bentuk kegiatan pendidikan/promosi kesehatan secara signifikan dapat meningkatkan nilai sikap orang tua menjadi lebih positif terhadap pemberian pendidikan seksual pada anak. Beberapa intervensi yang dapat diberikan yaitu berupa konseling, pelatihan dan pendidikan seksual bagi orang tua, drama edukasi dengan melibatkan orang tua dan anak, serta kursus harian. Pemilihan metode dan media dapat disesuaikan dengan target dan sasaran. Intervensi satu dengan yang lainnya memiliki kekurangan serta kelebihannya masing-masing, tingkat keefektifannyapun berbedabeda.
Berdasarkan hasil analisis 10 jurnal, beberapa metode intervensi program pendidikan seksual yang efektif untuk diterapkan di Indonesia, yaitu : 1) metode kursus harian yang bersifat estafet dengan melibatkan anak dan orang tua secara langsung; 2) drama edukasi yang dimainkan langsung oleh anak-anak diiringi dengan lagu yang menyenangkan; dan 3) penggunaan lembar worksheet sebagai alat untuk orang tua menyusun konsep pendidikan seksual untuk anak mereka sesuai kehendak mereka dengan tetap mendapat arahan dari fasilitator.

Metode yang melibatkan anak di dalamnya akan membuat orang tua dan anak memiliki pengalaman yang nyata. Pengalaman langsung akan melibatkan seluruh pengindraan manusia termasuk perasaan. Sedangkan, metode yang umum digunakan seperti ceramah dan metode diskusi kelompok perlu dikembangkan sehingga menarik dan tidak membosankan. Metode ceramah satu kali pertemuan kurang efektif digunakan untuk mengubah sikap dan perilaku seseorang karena memiliki retensi penyimpanan yang rendah.

Peningkatan sikap orang tua yang lebih positif dalam memberikan pendidikan seksual pada anak diikuti dengan perilaku/tindakan nyata akan membuat anak menjadi lebih paham terkait masalah seksual yang ada pada dirinya dan bagaimana ia dapat melindungi diri dari kondisi-kondisi yang tidak diinginkan sehingga diharapkan pembekalan yang cukup tentang masalah seksual sejak dini dapat menjadi sebuah langkah preventif kasus pelecehan seksual anak. 


\section{DAFTAR PUSTAKA}

1. KPAI. 2019. Jumlah Kasus Anak Korban Pelecehan Seksual. (https://www.cnnindonesia.com/nasi onal/20190803195708-12-

418125/polri-sebut-236-kasuspornografi-terjadi-sepanjang-2019 diakses 10 April 2020)

2. Noviana I., 2015. Kekerasan Seksual terhadap Anak: Dampak dan Penanganannya Child Sexual Abuse: Impact and Hendling. Pusat Penelitian dan Pengembangan Kesejahteraan Sosial, Kementerian Sosial RI

3. Anggraini T., 2017. Pendidikan seks pada anak usia 4-5 tahun. Tugas Akhir, Program Studi Pendidikan Anak Usia Dini Universitas Lampung, Lampung.

4. Ratnasari., Risa F.M., dan Alias., 2016. Pentingnya Pendidikan Seks Untuk Anak Usia Dini. Jurnal' Tarbawi Khatulistiwa', Vol.2 No. 2 2016 ISSN : 2442-756X.

5. Wooden C.L. and Anderson F.R., 2012. Enganging Parent in Reproductive Health Education: lesson leaned implementing a parent designed, peer-led educational model for parents of preteens. $A m \mathrm{~J}$ Sex Educ. 2012;7(4):461-73.

6. Buhori., 2017. Pendidikan Seks pada Anak Usia Dini. IAIN, Pontianak.

7. Septiani E., Prawitasari S., dan Emilia O., 2016. Efektivitas promosi kesehatan menggunakan audiovisual terhadap perubahan persepsi ibu tentang pendidikan seks untuk anak prasekolah. Berita Kedokteran Masyarakat, 32(11), 421-426.

8. Gesser E.A., Fridman T., and Lev W.R., 2017. Edutainment as a Strategy for Parental Discussion With Israeli Children: The Potential of a Children's Play in Preventing Sexual Abuse. Journal of Child Sexual Abuse, 26(5), 553-572. (https://doi.org/10.1080/10538712.2 $017.1319003)$

9. Martin J., Riazi H., Firoozi A., and Nasiri M., 2018. A sex education programme for mothers in Iran: Does preschool children's sex education influence mothers' knowledge and attitudes?. Sex Education, 18(2), 219-230. (https://doi.org/10.1080/14681811.2 018.1428547 )

10. Lak P., Noroozi M., and Ehsanpoor S., 2018. Comparing the effect of two methods of group education and education by multimedia compact disk on mothers' knowledge and attitude about child sexual abuse. Annals of Tropical Medicine and Public Health, 10(6), 1720.

11. Navaei, M., Akbari-Kamrani, M., Esmaelzadeh-Saeieh, S., Farid, M., \& Tehranizadeh, M. 2018. Effect of group counseling on parents' selfefficacy, knowledge, attitude, and communication practice in preventing sexual abuse of children aged 2-6 years: A randomized controlled clinical trial. International Journal of Community Based Nursing and Midwifery, 6(4), 285292.

https://doi.org/10.30476/ijcbnm.2018 .40834

12. Mobredi, K., Hasanpoor A.S.B., Azi S.A., Haghani $H_{\text {., }}$ and Farahani L.A., 2018. Effect of the sexual education program on the knowledge and attitude of preschoolers' mothers. Journal of Clinical and Diagnostic Research, 12(6), JC06-JC09. (https://doi.org/10.7860/JCDR/2018/ 32702.11616)

13. Rousta R., Najmabadi K., Asgharipour N., and Saki A., 2019. Effects of Group Training on 
Maternal Knowledge and Attitude toward Sexual Health Education to 12 to 14 Years old Boys. Journal of Midwifery \& Reproductive Health, $7(4)$, 1936-1945. (https://doi.org/10.22038/jmrh.2019. 29106.1313)

14. Apaydın C.V., Efe E., and Velipaşaoğlu S., 2020. Educating children through their parents to prevent child sexual abuse in Turkey. Perspectives in Psychiatric Care, 56(3), 523-532. (https://doi.org/10.1111/ppc.12461)

15. Lee P.I. et al., 2020. Effects of a parenting sexual education program for immigrant parents: A cluster randomized trial. Patient Education and Counseling, 103(2), 343-349. (https://doi.org/10.1016/j.pec.2019.0 8.027)

16. Joni I.D.A.M. dan Surjaningrum E.R., $2020 . \quad$ Psikoedukasi Pendidikan Seks Kepada Guru dan Orang Tua Sebagai Upaya Pencegahan Kekerasan Seksual Pada Anak. Jurnal Diversita, 6(1),
20-27.

(https://doi.org/10.31289/diversita.v6 i1.3582)

17.Sari P.S., 2019. Analisis terhadap Kerucut Pengalaman Edgar Dale dan Keragaman Gaya Belajar untuk Memilih Media yang Tepat dalam Pembelajaran. Jurnal Manajemen Pendidikan. Vol. I No. 1, Januari 2019.

18. Susilowati D., 2016. Promosi Kesehatan. Kementrian Kesehatan Republik Indonesia.

19. Wang Y. et al., 2019. Integrating Taxonomies Into Theory-Based Digital Health Interventions for Behavior Change:A Holistic Framework. JMIR research protocols ; 8 (2019), 1. - e8055 (https://dx.doi.org/10.2196/resprot.8 055)

20. Matthew P.H.K. and Leandre R.F., 2017. Theory of Planned Behavior. Encyclopedia of Personality and Individual Differences, (DOI 10.1007/978-3-319-28099-8_11911) 